\title{
CuI/N4 ligand/TEMPO derivatives: A mild and highly efficient system for aerobic oxidation of primary alcohols
}

\author{
Shufang Zhang a,b, Chengxia Miao a,\#, Daqian Xu ${ }^{\text {a, }}$, Wei Sun ${ }^{a, *}$, Chungu Xia ${ }^{a}$ \\ a State Key Laboratory for Oxo Synthesis and Selective Oxidation, Lanzhou Institute of Chemical Physics, Chinese Academy of Sciences, Lanzhou 730000 , \\ Gansu, China \\ b University of Chinese Academy of Sciences, Beijing 100049, China
}

\section{A R T I C L E I N F O}

Article history:

Received 1 May 2014

Accepted 3 June 2014

Published 20 November 2014

\section{Keywords:}

Alcohol

Aerobic oxidation

Tetradentate nitrogen ligand

Copper

2,2,6,6-tetramethylpiperidine-1-oxyl

\begin{abstract}
A B S T R A C T
A new system consisting of a copper(I) complex generated in situ from a tetradentate nitrogen ligand and $\mathrm{CuI}$ in combination with 2,2,6,6-tetramethylpiperidine-1-oxyl (TEMPO) derivatives was successfully developed. The system was suitable for efficient and selective aerobic oxidation of primary benzyl and allyl alcohols with a wide range of functional groups to the corresponding aldehydes at room temperature. The best result was obtained with $N, N^{\prime}$-dimethyl- $N, N^{\prime}$-bis(2-pyridylmethyl)ethane-1,2-diamine as the ligand and 4-OH-TEMPO as a cocatalyst in $\mathrm{CH}_{3} \mathrm{CN}$. In addition, high-resolution mass spectrometry, ultraviolet-visible spectroscopy, and electrochemical experiments were used to provide evidence of intermediates.
\end{abstract}

(C) 2014, Dalian Institute of Chemical Physics, Chinese Academy of Sciences. Published by Elsevier B.V. All rights reserved.

dehydes or ketones is a common transformation in organic synthesis because aldehydes and ketones are important as intermediates in pharmaceuticals, plastic additives, perfumes, flavoring compounds, and certain dyes in the textile industry. Recently, the use of the stable nitroxyl radical 2,2,6,6-tetramethylpiperidine-1-oxyl (TEMPO) in combination with various oxidants in the oxidation of alcohols has attracted interest [11-13]. However, many TEMPO-based systems use stoichiometric amounts of terminal oxidants such as sodium chlorite and hypervalent iodine(III) compounds, so large amounts of waste are produced $[14,15]$, and longer reaction time or high temperature is also often needed [16].

Air, oxygen, and hydrogen peroxide are clean oxidants, and only water is formed as the by-product, so they have been attracting much interest for use in green chemistry. However, TEMPO, which is expensive, cannot be regenerated directly by

\footnotetext{
* Corresponding author. Fax: +86-931-8277088; E-mail: wsun@licp.cas.cn

\# Corresponding author. E-mail: chxmiao@licp.cas.cn

This work was supported by the National Natural Science Foundation of China $(21103207,21133011)$.

DOI: 10.1016/S1872-2067(14)60161-3 | http://www.sciencedirect.com/science/journal/18722067 | Chin. J. Catal., Vol. 35, No. 11, November 2014
} 
molecular oxygen alone, so a cocatalyst is required for activation of molecular oxygen [17].

Copper complexes are more attractive as they are biomimetic functional models of the mononuclear copper enzyme galactose [18]. In 1984, Semmelhack et al. [19] reported the aerobic oxidation of allyl and benzyl alcohols to the corresponding aldehydes and ketones catalyzed by $10 \mathrm{~mol} \% \mathrm{CuI} /$ TEMPO in $N, N$-dimethylformamide (DMF) at room temperature. Subsequent research mainly focused on the choice and design of nitrogen-containing ligands such as 1,10-phenanthroline [20], 2,2'-bipyridine (bpy) [21-25], 1,4-diazabicyclo[2.2.2] octane [26], 4-pyrrolidinopyridine [27], pyrazole-pyridine [28], salen- $\mathrm{H}_{4}$ [29], and 1,4,7-triazacyclononane [30] to improve the catalytic activity and extend the substrate scope. Recently, a breakthrough was achieved by Stahl and coworkers [21-25]. They used $\mathrm{N}$-methylimidazole as an additive in a CuI-bpy/ TEMPO catalyst system for the highly selective and efficient transformation of a broad range of alcohols, including allylic, benzyl, and aliphatic derivatives, with heterocycles and other heteroatom-containing groups. It should be noted that this catalyst system used non-commercial $\mathrm{Cu}^{\mathrm{I}}(\mathrm{OTf})$ as the copper source.

Although significant progress has been made in developing TEMPO/Cu catalyst systems, readily available systems for the efficient oxidation of alcohols under mild conditions are still needed. In our continuing efforts to develop new systems for oxidation of alcohols catalyzed by TEMPO derivatives [31-34] and new applications of $\mathrm{N} 4$ ligands in different reactions [8-10], we considered that a tetradentate nitrogen ligand (Scheme 1) combined with copper(I) ions and TEMPO derivatives might be active in oxidation of alcohols. We found that an easily obtainable catalyst system comprising CuI, $N, N^{\prime}$-dimethyl- $N, N^{\prime}$-bis(2-pyridylmethyl)ethane-1,2-diamine (BPMEN), and 4-OH-TEMPO exhibited high efficiency and wide substrate scope, including allylic, benzyl, and aliphatic primary alcohols, at room temperature using air as the oxidant without any additives such as a base.

\section{Experimental}

\subsection{General information}

Gas chromatography-mass spectrometry (GC-MS) was performed using an Agilent Technologies 7890A/5975C system. ${ }^{1} \mathrm{H}$

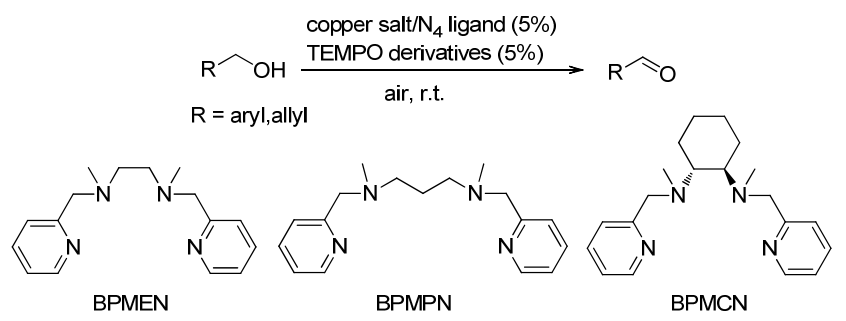

Scheme 1. Oxidation of alcohols catalyzed by copper salt/TEMPO derivative/N4 ligand. BPMEN $=N, N^{\prime}$-dimethyl- $N, N^{\prime}$-bis(2-pyridylmethyl) ethane-1,2-diamine, BPMPN $=N, N^{\prime}$-dimethyl- $N, N^{\prime}$-bis(2-pyridinylmethyl)propane-1,3-diamine, BPMCN = trans- $N, N^{\prime}$-dimethyl- $N, N^{\prime}$-bis $(2-$ pyridylmethyl)cyclohexane-1,2-diamine. and ${ }^{13} \mathrm{C}$ nuclear magnetic resonance (NMR) spectra were recorded using a Bruker Avance III $400 \mathrm{MHz}$ spectrometer. The chemical shifts $(\delta)$ are reported in parts per million (ppm) and coupling constants $($ ) in $\mathrm{Hz}$. GC analysis was performed using an Agilent Technologies 6820 instrument with a flame-ionization detector. High-resolution (HR) MS was performed using a Bruker Daltonics micrOTOF-QII mass spectrometer. Ultraviolet (UV)-visible spectra were recorded using an Agilent Cary 60 spectrometer. Electrochemical measurements were conducted with a $\mathrm{CHI} 660 \mathrm{E}$ potentiostat using a platinum-button working electrode, non-aqueous $\mathrm{Ag} / \mathrm{Ag}^{+}$reference, and a platinum wire counter electrode at a scan rate of $100 \mathrm{mV} / \mathrm{s}$. Elemental analysis was performed using a Vario EL cube elemental analyzer.

\subsection{Preparation and characterization of ligands and Cu(BPMEN)I complex}

The ligands, i.e., BPMEN, BPMPN, and BPMCN, were synthesized as previously reported [35,36].

BPMEN: ${ }^{1} \mathrm{H}$ NMR $\left(\mathrm{CDCl}_{3}\right) \delta=8.54(\mathrm{ddd}, J=4.9,1.7,0.8 \mathrm{~Hz}$, 2H), 7.63 (td, $J=7.7,1.8 \mathrm{~Hz}, 2 \mathrm{H}$ ), 7.42 (d, $J=7.8 \mathrm{~Hz}, 2 \mathrm{H}$ ), 7.14 (ddd, $J=7.4,4.9,1.0 \mathrm{~Hz}, 2 \mathrm{H}), 3.69(\mathrm{~s}, 4 \mathrm{H}), 2.65(\mathrm{~s}, 4 \mathrm{H}), 2.28$ (s, $6 \mathrm{H}) ;{ }^{13} \mathrm{C} \mathrm{NMR}\left(\mathrm{CDCl}_{3}\right) \delta=159.4,149.1,136.3,123.0,121.9,64.2$, 55.5, 42.9 .

BPMPN: ${ }^{1} \mathrm{H}$ NMR $\left(\mathrm{CDCl}_{3}\right) \delta=8.53(\mathrm{~d}, J=4.5 \mathrm{~Hz}, 2 \mathrm{H}), 7.63(\mathrm{t}, J$ $=8.4 \mathrm{~Hz}, 2 \mathrm{H}), 7.39(\mathrm{~d}, J=7.8 \mathrm{~Hz}, 2 \mathrm{H}), 7.14(\mathrm{dd}, J=6.8,5.5 \mathrm{~Hz}$, $2 \mathrm{H}), 3.65(\mathrm{~s}, 4 \mathrm{H}), 2.54-2.44(\mathrm{~m}, 4 \mathrm{H}), 2.25(\mathrm{~s}, 6 \mathrm{H}), 1.83-1.73(\mathrm{~m}$, $2 \mathrm{H}) ;{ }^{13} \mathrm{C} \mathrm{NMR}\left(\mathrm{CDCl}_{3}\right) \delta=159.5,149.0,136.3,123.0,121.9,63.9$, 55.8, 42.5, 25.2.

BPMCN: ${ }^{1} \mathrm{H}$ NMR $\left(\mathrm{CDCl}_{3}\right) \delta=8.42(\mathrm{dt}, J=4.9,1.3 \mathrm{~Hz}, 2 \mathrm{H})$, 7.53-7.49 (m, 4H), 7.08-7.01 (m, 2H), 3.79 (dd, $J=48.3,14.6$ $\mathrm{Hz}, 4 \mathrm{H}), 2.65-2.55$ (m, 2H), 2.22 (s, 6H), 1.92 (dd, $J=10.4,2.4$ $\mathrm{Hz}, 2 \mathrm{H}), 1.74-1.65(\mathrm{~m}, 2 \mathrm{H}), 1.22(\mathrm{td}, J=12.3,6.4 \mathrm{~Hz}, 2 \mathrm{H})$, 1.13-1.05 (m, 2H); ${ }^{13} \mathrm{C}$ NMR $\left(\mathrm{CDCl}_{3}\right) \delta=161.2,148.6,136.3$, 123.0, 121.6, 64.5, 60.4, 36.7, 25.8, 25.8.

CuI $(0.25 \mathrm{mmol})$ and BPMEN $(0.25 \mathrm{mmol})$ were added to $\mathrm{CH}_{3} \mathrm{CN}(1 \mathrm{~mL})$ in an $\mathrm{Ar}$ atmosphere, and the mixture was stirred at room temperature for $2 \mathrm{~h}$. After the reaction, the solvent was removed under vacuum to yield a Cu(BPMEN)I complex, which was then washed with $\mathrm{CH}_{3} \mathrm{CN}$ and diethyl ether and dried under vacuum. HRMS (ESI-MS) calcd for $\mathrm{C}_{16} \mathrm{H}_{22} \mathrm{CuN}_{4}[M-$ I]+: 333.1121; found: 333.1135. Anal. calcd for $\mathrm{C}_{16} \mathrm{H}_{22} \mathrm{CuN}_{4} \mathrm{I}$. 0.7MeCN: C 42.84\%, H 5.12\%, N 13.38\%; found C $42.69 \%, \mathrm{H}$ $4.96 \%$, N $13.45 \%$.

\subsection{Typical procedure for oxidation of alcohols}

The copper salt and the ligand (each $0.025 \mathrm{mmol}$ ) were added to $\mathrm{CH}_{3} \mathrm{CN}(1 \mathrm{~mL})$ in an Ar atmosphere and stirred for 30 min. Then 4-OH-TEMPO (0.025 mmol) and substrate $(0.5$ mmol) were added successively, and the mixture was stirred at room temperature. The reaction progress was checked using thin-layer chromatography. The reaction conversion and yield were obtained from GC measurements using nitrobenzene or nonane as an internal standard, or by column chromatography.

\subsection{NMR data of some products}


Phenylpropargyl aldehyde: ${ }^{1} \mathrm{H}$ NMR $\left(\mathrm{CDCl}_{3}\right) \delta=9.34(\mathrm{~s}, 1 \mathrm{H})$, 7.51 (dd, $J=5.2,3.2 \mathrm{~Hz}, 2 \mathrm{H}), 7.43-7.37(\mathrm{~m}, 1 \mathrm{H}), 7.32(\mathrm{t}, J=7.5$ $\mathrm{Hz}, 2 \mathrm{H}) ;{ }^{13} \mathrm{C} \mathrm{NMR}\left(\mathrm{CDCl}_{3}\right) \delta=175.7,132.3,130.3,127.7,118.4$, 94.1, 87.4.

$\alpha$-Methylcinnamaldehyde: ${ }^{1} \mathrm{H}$ NMR $\left(\mathrm{CDCl}_{3}\right) \delta=9.47(\mathrm{~s}, 1 \mathrm{H})$, 7.45-7.39 (m, 2H), 7.38-7.25 (m, 3H), 7.16 (d, $J=6.7 \mathrm{~Hz}, 1 \mathrm{H})$, $1.97(\mathrm{~d}, J=1.3 \mathrm{~Hz}, 3 \mathrm{H}) ;{ }^{13} \mathrm{C} \mathrm{NMR}\left(\mathrm{CDCl}_{3}\right) \delta=195.5,149.8,138.3$, 135.2, 130.1, 129.6, 128.7, 10.9 .

Neral: ${ }^{1} \mathrm{H}$ NMR $\left(\mathrm{CDCl}_{3}\right) \delta=9.82(\mathrm{~d}, J=8.2 \mathrm{~Hz}, 1 \mathrm{H}), 5.80(\mathrm{~d}, J=$ $8.2 \mathrm{~Hz}, 1 \mathrm{H}), 5.07-4.99(\mathrm{~m}, 1 \mathrm{H}), 2.51(\mathrm{t}, J=7.5 \mathrm{~Hz}, 2 \mathrm{H}), 2.16(\mathrm{q}, J$ = 7.4 Hz, 2H), $1.91(\mathrm{~d}, J=1.2 \mathrm{~Hz}, 3 \mathrm{H}), 1.61(\mathrm{~s}, 3 \mathrm{H}), 1.52(\mathrm{~s}, 3 \mathrm{H})$; ${ }^{13} \mathrm{C}$ NMR $\left(\mathrm{CDCl}_{3}\right) \delta=190.7,163.7,133.6,128.6,122.3,32.5$, 27.0, 25.6, 25.0, 17.7 .

\section{Results and discussion}

\subsection{Optimization of reaction conditions}

Exploratory experiments were performed to test this protocol and screen the reaction conditions using benzyl alcohol as the model substrate (Table 1). The copper complex was generated from a copper salt and N4 ligand, which were stirred for 30 min before every reaction. The copper salt, TEMPO, and N4 ligand were essential in the aerobic oxidation of benzyl alcohol (Table 1, entries 1-3 vs 15-17). Initially, three different ligands, BPMEN, BPMPN, and BPMCN (Scheme 1), in combination with $\mathrm{CuBr}$ were used in the oxidation of benzyl alcohol under the

\section{Table 1}

Oxidation of benzyl alcohol catalyzed by TEMPO/copper salt/N4 ligand, using air as oxidant.

\begin{tabular}{|c|c|c|c|c|}
\hline Entry & Cu salt & Solvent & Conversiona (\%) $^{2}$ & Yield a(\%) \\
\hline 1 & $\mathrm{CuBr}$ & $\mathrm{CH}_{3} \mathrm{CN}$ & $69(88)$ & $66(86)^{b}$ \\
\hline 2 & $\mathrm{CuBr}$ & $\mathrm{CH}_{3} \mathrm{CN}$ & 37 (77) & $33(75)^{c}$ \\
\hline 3 & $\mathrm{CuBr}$ & $\mathrm{CH}_{3} \mathrm{CN}$ & 71 (>99) & $69(99)$ \\
\hline 4 & $\mathrm{CuBr}$ & $\mathrm{CH}_{2} \mathrm{Cl}_{2}$ & 35 & 32 \\
\hline 5 & $\mathrm{CuBr}$ & THF & 52 & 48 \\
\hline 6 & $\mathrm{CuBr}$ & DMF & 46 & 40 \\
\hline 7 & $\mathrm{CuBr}$ & hexane & - & - \\
\hline 8 & $\mathrm{CuBr}$ & 1,4-dioxane & 18 & 17 \\
\hline 9 & $\mathrm{CuBr}$ & toluene & 29 & 28 \\
\hline 10 & $\mathrm{CuBr}$ & DMSO & 55 & 46 \\
\hline 11 & $\mathrm{CuBr}$ & acetone & 60 & 50 \\
\hline 12 & $\mathrm{CuI}$ & $\mathrm{CH}_{3} \mathrm{CN}$ & 94 & 92 \\
\hline 13 & $\mathrm{CuCl}$ & $\mathrm{CH}_{3} \mathrm{CN}$ & 49 & 46 \\
\hline 14 & $\mathrm{Cu}(\mathrm{MeCN})_{4} \mathrm{BF}_{4}$ & $\mathrm{CH}_{3} \mathrm{CN}$ & 51 & 46 \\
\hline 15 & $\mathrm{CuI}$ & $\mathrm{CH}_{3} \mathrm{CN}$ & 9 & $8^{d}$ \\
\hline 16 & - & $\mathrm{CH}_{3} \mathrm{CN}$ & - & $0 \mathrm{e}$ \\
\hline 17 & CuI & $\mathrm{CH}_{3} \mathrm{CN}$ & 10 & $7^{f}$ \\
\hline 18 & $\mathrm{CuCl}_{2}$ & $\mathrm{CH}_{3} \mathrm{CN}$ & trace & trace \\
\hline 19 & $\mathrm{CuBr}_{2}$ & $\mathrm{CH}_{3} \mathrm{CN}$ & trace & trace \\
\hline
\end{tabular}

Reaction conditions: $\mathrm{CuX} \mathrm{(10 \% )} \mathrm{and} \mathrm{BPMEN} \mathrm{(10 \% )} \mathrm{in} 1 \mathrm{~mL}$ of solvent were stirred for $30 \mathrm{~min}$ at room temperature under Ar; benzyl alcohol $(0.5 \mathrm{mmol})$ and TEMPO (10\%) were added, and the mixture was stirred for another $30 \mathrm{~min}$ in air.

a Conversion and yield were determined by GC using nitrobenzene as the internal standard. The number in parentheses indicates a reaction time of 50 min.

bBPMPN was used instead of BPMEN.

'BPMCN was used instead of BPMEN.

dStirring at $\mathrm{rt}$ for $24 \mathrm{~h}$ without TEMPO.

eStirring at $\mathrm{rt}$ for $24 \mathrm{~h}$ without $\mathrm{CuI}$ and BPMEN.

fStirring at $\mathrm{rt}$ for $24 \mathrm{~h}$ without BPMEN. same conditions; BPMEN proved to be the best ligand choice (Table 1, entries 1-3), giving 99\% yield after prolonging the reaction time to $50 \mathrm{~min}$ (Table 1 , entry 3 ). A series of organic solvents were then systematically investigated (Table 1, entries 3-11). The results indicated that the solvent had a significant effect on the oxidation reaction, and 69\% yield was obtained in $\mathrm{CH}_{3} \mathrm{CN}$ within $30 \mathrm{~min}$. The oxidation did not proceed in hexane; this may be attributable to the insolubility of the in situ-generated copper complex or failure to form the corresponding copper complex. A series of copper salts, i.e., $\mathrm{CuCl}$, $\mathrm{CuI}$, and $\mathrm{Cu}(\mathrm{MeCN})_{4} \mathrm{BF}_{4}$, were also screened; the best catalytic performance was obtained using $\mathrm{CuI}$ as the copper source (Tabel 1, entries 3 and 12-14). $\mathrm{CuCl}_{2}$ and $\mathrm{CuBr}_{2}$ were inert in the reaction, unlike the case for the bpy-Cu system reported by Stahl et al. [21].

The effects of TEMPO derivatives on the reaction were also examined. Most tested TEMPO derivatives gave above $90 \%$ conversions and yields, except $4-\mathrm{CH}_{3} \mathrm{SO}_{2} \mathrm{O}$-TEMPO (Table 2, entries 1-7). 4-OH-TEMPO gave nearly quantitative conversion and yield and proved to be the most efficient TEMPO derivative when the oxidation was carried out in the presence of $10 \% \mathrm{CuI}$ and BPMEN in air for $30 \mathrm{~min}$. The 4-OH-TEMPO, CuI, and BPMEN loadings were then screened (Table 2, entries 8-10). A

Table 2

Oxidation of benzyl alcohol catalyzed by different TEMPO derivatives.

\begin{tabular}{|c|c|c|c|c|}
\hline Entry & R-TEMPO & $t / \mathrm{h}$ & Conversion $^{\mathrm{a}}(\%)$ & Yield a(\%) \\
\hline 1 & TEMPO & 0.5 & 94 & 92 \\
\hline 2 & & 0.5 & 95 & 91 \\
\hline 3 & & 0.5 & 90 & 89 \\
\hline 4 & & 0.5 & 96 & 94 \\
\hline 5 & & 0.5 & 76 & 70 \\
\hline 6 & & 0.5 & 96 & 93 \\
\hline 7 & & 0.5 & $>99$ & 99 \\
\hline 8 & & 0.5 & 99 & $91^{\mathrm{b}}$ \\
\hline 9 & & 1.5 & 99 & $88^{c}$ \\
\hline 10 & & 1 & 99 & $99^{d}$ \\
\hline
\end{tabular}

Reaction conditions: CuI (10\%) and BPMEN (10\%) in $1 \mathrm{~mL}$ of solvent were stirred for $30 \mathrm{~min}$ at room temperature in Ar; benzyl alcohol $(0.5$ mmol) and R-TEMPO (10\%) were added, and the mixture was stirred for another $30 \mathrm{~min}$ in air.

${ }^{a}$ Conversion and yield were determined by GC using nitrobenzene as the internal standard.

${ }^{\mathrm{b}} \mathrm{CuI}(5 \%)$, BPMEN (5\%), and HO-TEMPO (10\%) were used. ${ }^{\mathrm{c} C \mathrm{CuI}}(2 \%)$, BPMEN (2\%), and HO-TEMPO (10\%) were used. ${ }^{\mathrm{d}} \mathrm{CuI}$ (5\%), BPMEN (5\%), and HO-TEMPO (5\%) were used. 
91\% yield was still achieved with 5\% CuI, 5\% BPMEN, and 10\% 4-OH-TEMPO under the same conditions (Table 2, entry 8). When the loadings of $\mathrm{CuI}$ and BPMEN were further reduced to $2 \%$, a comparable yield was obtained by prolonging the reaction time to $1.5 \mathrm{~h}$ (Table 2, entry 9). Overall, the reaction proceeded smoothly with $5 \%$ each of 4-OH-TEMPO, CuI, and BPMEN, giving 99\% yield of aldehyde in $1 \mathrm{~h}$ (Table 2 , entry 10 ).

\subsection{Substrate scope and limitations}

To examine the utility and generality of the catalyst system in the oxidation of alcohols, we used it for the oxidation of various alcohols; the results are summarized in Table 3. All the primary aromatic alcohols with either electron-donating or electron-withdrawing groups on the benzene ring were smoothly converted to aldehydes, giving more than $85 \%$ yields of the desired products; no over-oxidization products were detected. It was found that the electronic properties and steric hindrance of the substituents on the benzene ring influence the reactivity of primary benzyl alcohols; for example, the reactivity of $p$-OMe-benzyl alcohol was better than those of $o$ - and $m$-OMe-benzyl alcohol (Table 3, entries 2-4). Benzyl alcohols bearing more electron-donating groups on the benzene ring exhibited higher reactivitiy (Tabel 3, entries 2-4 vs 5 and 6)
Moreover, stronger electron-donating groups promoted oxidation (Table 3, entries 2-4 vs 7 and 8).

Primary aromatic alcohols with electron-withdrawing groups on the benzene ring had poorer activity than the opposite ones, but comparable yields were obtained by prolonging the reaction time to $24 \mathrm{~h}$ in an oxygen atmosphere (Table 3, entries 9-12). A series of heterocyclic benzyl alcohols were also tested. Furfuryl alcohol and 2-thiophenemethanol gave yields of more than $90 \%$ (Table 3, entries 13 and 14 ), but only $8 \%$ yield of the desired product was obtained using pyridine-2-methanol as the substrate (Table 3, entry 15). The present protocol was also applicable to the oxidation of allylic alcohols such as cinnamyl alcohol, nerol, and 2-methyl-3-phenyl-2-propen-1-ol and gave good conversions (Table 3, entries 16-18). Propargyl alcohols such as 3-phenylprop-2-yn-1-ol also tolerated the optimized reaction conditions, affording the corresponding aldehyde in 51\% yield (Table 3 , entry 19). Unfortunately, the catalyst system was unsuitable for the oxidation of aliphatic alcohols and secondary alcohols, giving only $15 \%$ phenylacetaldehyde and $7 \%$ acetophenone, respectively (Table 3, entries 20 and 21).

The different reactivity of benzyl, allylic, and secondary alcohols suggest that the designed oxidation system should be chemoselective. We chose an equimolar mixture of benzyl al-

Table 3

Catalytic aerobic oxidation of various alcohols.

\begin{tabular}{|c|c|c|c|c|c|c|c|c|c|}
\hline Entry & Substrate & Product & $t / \mathrm{h}$ & 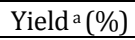 & Entry & Substrate & Product & $t / \mathrm{h}$ & Yield $^{\mathrm{a}}(\%)$ \\
\hline 1 & $\widehat{\mathrm{OH}}$ & & 1 & 99 & 12 & & & 24 & $90^{\mathrm{b}}$ \\
\hline 2 & $\mathrm{OCH}_{3}$ & $\mathrm{OCH}_{3}$ & 3 & 85 & 13 & & & 4 & $97^{c}$ \\
\hline 3 & & & 3 & 87 & 14 & & & 3 & 92 \\
\hline 4 & & & 3 & 93 & 15 & & & 24 & 8 \\
\hline 5 & & & 2 & 97 & 16 & & & 3 & 90 \\
\hline 6 & & & 2 & 90 & 17 & & & 3 & 71 \\
\hline 7 & & & 4 & 89 & 18 & & & 2 & 80 \\
\hline 8 & & & 4 & 86 & 19 & & & 24 & $51^{b}$ \\
\hline 9 & & & 24 & $89^{b}$ & 20 & & & 24 & $15^{\mathrm{d}}$ \\
\hline 10 & & & 24 & $87^{b}$ & 21 & & & 24 & $7^{\mathrm{d}}$ \\
\hline 11 & & & 24 & $85^{b}$ & & & & & \\
\hline
\end{tabular}

Reaction conditions: CuI (5\%) and BPMEN (5\%) in $1 \mathrm{~mL}$ of solvent were stirred for $30 \mathrm{~min}$ at room temperature in Ar; benzyl alcohol (0.5 $\mathrm{mmol}$ ) and 4-OH-TEMPO (5\%) were added, and the mixture was stirred for a certain time in air at room temperature.

${ }^{\mathrm{a}}$ Isolated yield. ${ }^{\mathrm{b}}$ Reaction conditions: $25^{\circ} \mathrm{C}$ with oxygen balloon. ${ }^{\mathrm{c}}$ Determined by GC. ${ }^{\mathrm{d}}$ Reaction conditions: $50{ }^{\circ} \mathrm{C}$ with oxygen balloon. 
cohol and 1-phenylethanol (0.5 mmol each) as intermolecular oxidation substrates for the reaction under the optimized reaction conditions. The benzyl alcohol was completely transformed to benzaldehyde and 1-phenylethanol was recovered completely after $0.5 \mathrm{~h}$. These results clearly demonstrate the excellent chemoselectivity of the $\mathrm{Cu}$ (BPMEN)I/TEMPO system in the aerobic oxidation of alcohols, providing considerable potential advantages in synthetic organic chemistry.

Semmelhack et al. [19] proposed that an oxoammonium species was involved in CuCl/TEMPO-catalyzed aerobic alcohol oxidation with DMF as the solvent, and oxoammonium involvement in alcohol oxidation is well known in many catalyst systems [37-39]. Based on kinetic experiments, Stahl et al. [21-25] showed that TEMPO $^{+}$is not the active oxidant in the $\mathrm{Cu}$ (bpy)/TEMPO catalyst system. Their electrochemical studies also indicated that copper(II) cannot oxidize TEMPO to $\mathrm{TEMPO}^{+}$under their reaction conditions. Based on the similarity to Stahl's system [21-25], electrochemical experiments were performed on a $\mathrm{CH}_{3} \mathrm{CN}$ solution of $\mathrm{CuI}$, BPMEN, and 4-OH-TEMPO (each $0.06 \mathrm{mmol}$ ) after stirring at room temperature for $5 \mathrm{~min}$ in Ar atmosphere. The cyclic voltammogram of our developed system shows reversible redox potentials at 0.35 and $-0.09 \mathrm{~V}$ (vs Fc$+\mathrm{Fc}$ ), corresponding to 4-OH-TEMPO ${ }^{+}$/ 4-OH-TEMPO and $\mathrm{Cu}^{\mathrm{II}} / \mathrm{Cu}^{\mathrm{I}}$, respectively (Fig. 1). In the case of 4-OH-TEMPO+/4-OH-TEMPO, the one-electron reduction potential is approximately equal to that observed with a solution

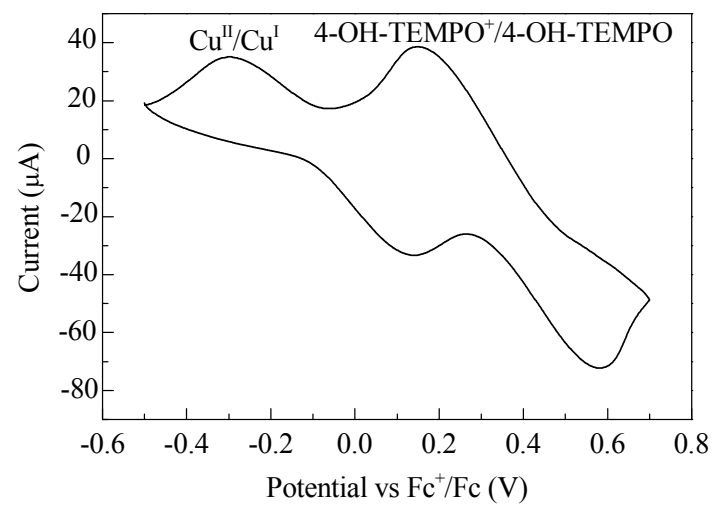

Fig. 1. Cyclic voltammogram of $\mathrm{Cu}(\mathrm{BPMEN}) \mathrm{I} / 4-\mathrm{OH}-\mathrm{TEMPO}$ in $\mathrm{CH}_{3} \mathrm{CN}$ under Ar. Conditions: $0.6 \mathrm{mmol} \mathrm{CuI,} 0.6 \mathrm{mmol}$ BPMEN, $0.6 \mathrm{mmol}$ TEMPO, $300 \mathrm{mg} \mathrm{LiClO}_{4}$, scan rate $100 \mathrm{mV} / \mathrm{s}$.

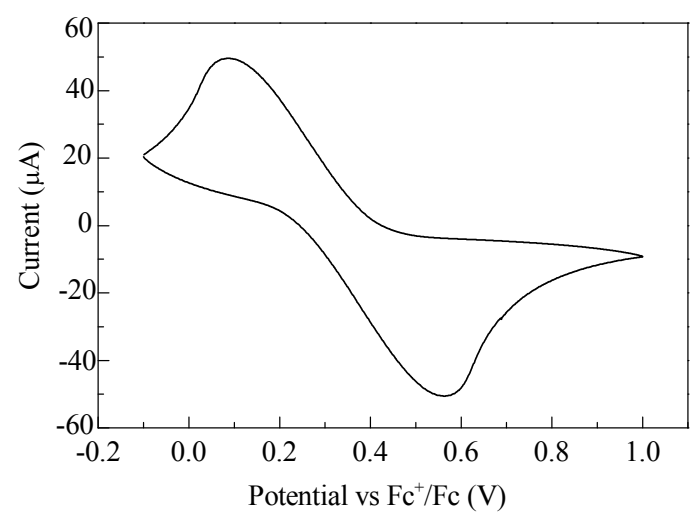

Fig. 2. Cyclic voltammogram of 4-OH-TEMPO under Ar. containing only 4-OH-TEMPO (Fig. 2). However, the one-electron reduction potential shifts from 0.3 to $-0.09 \mathrm{~V}\left(\mathrm{vs} \mathrm{Fc}^{+} / \mathrm{Fc}\right.$ ) in the presence of BPMEN (Figs. 3 and 4). This indicates that the BPMEN ligand coordinated with $\mathrm{CuI}$, leading to an increase in the overall electron density of the metal ion, resulting in a large negative shift in the reduction potential. This finding is in good accord with Stahl's system [21]. Copper(II) cannot oxidize 4-OH-TEMPO to 4-OH-TEMPO+ in our catalyst system.

Electron-spray ionization (ESI)-MS is an effective method for the characterization of reaction mechanisms [40]. An equimolar mixture of $\mathrm{CuI}$ and BPMEN was stirred for $30 \mathrm{~min}$, and a major peak appeared at $M_{\mathrm{r}} / z=333.1121$; it was assigned to [Cu(BPMEN)]+ (calculated: $M_{\mathrm{r}} / z=333.1135$ ). The formation of the Cu(BPMEN)I complex was also confirmed by elemental analysis. Then 4-OH-TEMPO was added to a copper complex generated from $\mathrm{CuI}$ and BPMEN and exposed to air or Ar. The peak corresponding to 4-OH-TEMPO $\left([\mathrm{M}+\mathrm{Na}]^{+} M_{\mathrm{r}} / z=\right.$ 195.1227) was not detected when the system was exposed to air, but the 4-OH-TEMPO peak was clearly observed under Ar. These results indicate that the transformation of 4-OH-TEMPO must be assisted by both the $\mathrm{Cu}(\mathrm{BPMEN}) \mathrm{I}$ complex and oxygen.

UV-visible spectroscopy was also performed to obtain an insight into the mechanism. An equimolar mixture of $\mathrm{CuI}$ and BPMEN ( $5 \mathrm{mmol} / \mathrm{L}$ in $\mathrm{CH}_{3} \mathrm{CN}$ ) was stirred in $\mathrm{Ar}$ atmosphere for $30 \mathrm{~min}$; the maximum absorption was located at $705 \mathrm{~nm}$ (Cu(BPMEN)I complex); the maximum absorption of 4-OH-TEMPO ( $5 \mathrm{mmol} / \mathrm{L}$ in $\mathrm{CH}_{3} \mathrm{CN}$ ) added to the above mixture in air was $810 \mathrm{~nm}$ (Fig. 5). When oxidation took place after the

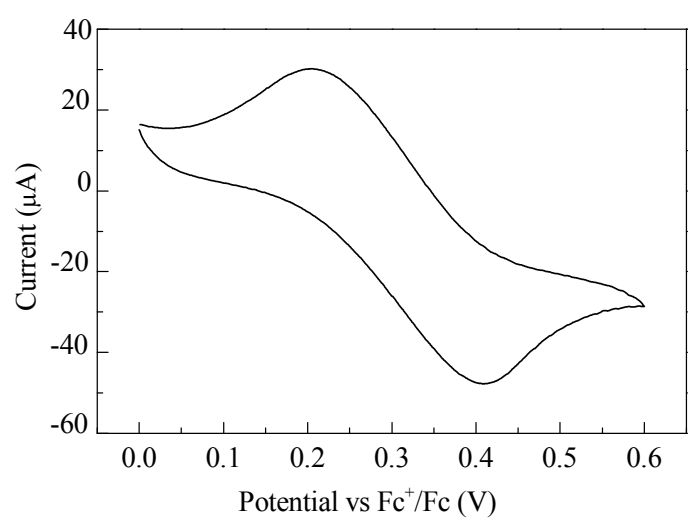

Fig. 3. Cyclic voltammogram of CuI under Ar.

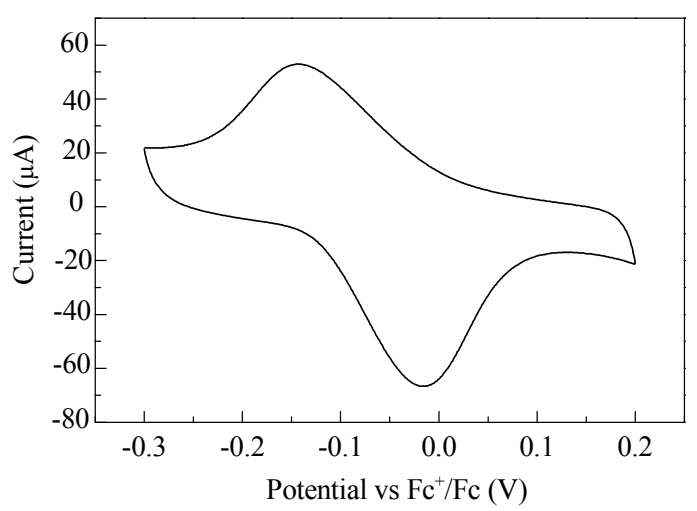

Fig. 4. Cyclic voltammogram of CuI + BPMEN (1:1) under Ar. 


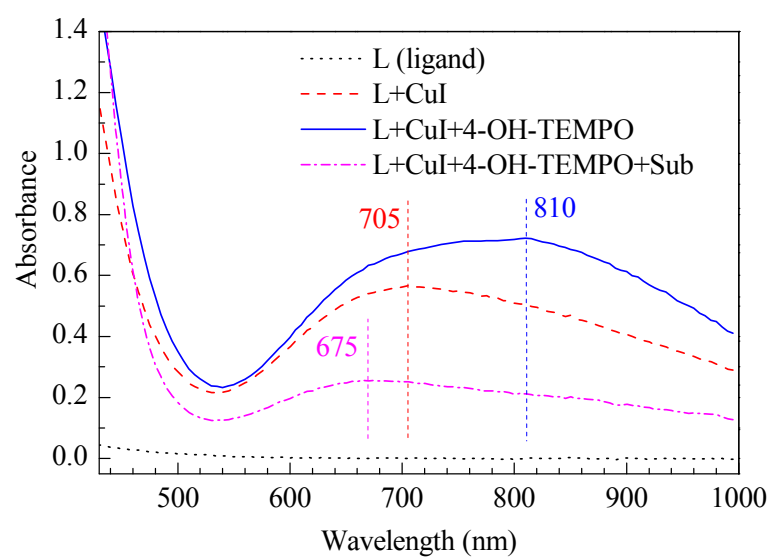

Fig. 5. UV-vis spectra in $\mathrm{CH}_{3} \mathrm{CN}$. Conditions: $5 \mathrm{mmol} / \mathrm{L}$ BPMEN, 5 $\mathrm{mmol} / \mathrm{L} \mathrm{CuI,} 5 \mathrm{mmol} / \mathrm{L}$ 4-OH-TEMPO in $\mathrm{CH}_{3} \mathrm{CN}$.

addition of benzyl alcohol, the intensity of the absorption peak at $810 \mathrm{~nm}$ gradually decreased, and a new shoulder appeared at $675 \mathrm{~nm}$ as the reaction proceeded. This indicates that the species causing the absorption at $810 \mathrm{~nm}$ may be the real intermediate responsible for the oxidation of alcohols.

\section{Conclusions}

We developed an easily obtained and efficient catalyst system consisting of CuI, BPMEN, and 4-OH-TEMPO for aerobic oxidation of primary alcohols under mild conditions. In all cases, primary benzyl and allylic alcohols were selectively oxidized to the corresponding aldehydes, and no over-oxidized products such as carboxylic acids were observed. The catalyst system exhibited excellent chemoselectivity for the oxidation of primary alcohols. Electrochemical experiments further revealed that copper(II) was not able to oxidize 4-OH-TEMPO to 4-OHTEMPO $^{+}$. HRMS confirmed that the transformation of 4-OHTEMPO must be assisted by both the Cu(BPMEN)I complex and air. The UV-visible spectra clearly indicated that a new species was formed in the presence of the Cu(BPMEN)I complex and 4-OH-TEMPO in air, which showed good reactivity in alcohol oxidation. More investigations of the proposed mechanism and application of the $\mathrm{Cu}(\mathrm{BPMEN}) \mathrm{I} / 4-\mathrm{OH}-\mathrm{TEMPO})$ catalyst system to oxidation reactions are underway in our laboratory.

\section{References}

[1] de Montellano P R 0. Cytochrome P450: Structure, Mechanism, and Biochemistry. 2nd Ed. New York: Plenum Press, 1995

[2] Turlington C R, White P S, Brookhat M, Templeton J L. J Am Chem Soc, 2014, 136: 3981

[3] Jacobsen E N. In: Abel E W, Stone F G A, Wilkinson G Eds. Comprehensive Organometallic Chemistry II. Oxford (UK): Pergamon, 1995

[4] McDonald A R, Que L Jr. Coord Chem Rev, 2013, 257: 414

[5] White M C, Doyle A G, Jacobsen E N. J Am Chem Soc, 2001, 123: 7194

[6] Prat I, Font D, Company A, Junge K, Ribas X, Beller M, Costas M. Adv Syn Catal, 2013, 355: 947

[7] Chen M S, White M C. Science, 2007, 318: 783

[8] Wu M, Wang B, Wang S F, Xia C G, Sun W. Org Lett, 2009, 11: 3622

[9] Wang B, Miao C X, Wang S F, Xia C G, Sun W. Chem Eur J, 2012, 18 : 6750

[10] Wang B, Wang S F, Xia C G, Sun W. Chem Eur J, 2012, 18: 7332

[11] Sheldon R A, Arends I W C E, ten Brink G J, Dijksman A. Acc Chem Res, 2002, 35: 774

[12] Zhang H, Fu L L, Zhong H M. Chin J Catal (张华, 付罗岭, 钟红敏. 催化学报), 2013, 34: 1848

[13] Wang L Y, Li J, Lv Y, Zhao G D, Gao S. Appl Organomet Chem, 2012, 26: 37

[14] Fritz-Langhals E. Org Process Res Dev, 2005, 9: 577

[15] Mu R Z, Liu Z Q, Yang Z J, Liu Z G, Wu L M, Liu Z L. Adv Synth Catal, 2005, 347: 1333

[16] Yu Y L, Gao B J, Li Y F. Chin J Catal (余依玲, 高保娇, 李艳飞. 催化 学报), 2013, 34: 1776

[17] Vogler T, Studer A. Synthesis, 2008: 1979

[18] Sasano Y, Nagasawa S, Yamazaki M, Shibuya M, Park J, Iwabuchi Y. Angew Chem Int Ed, 2014, 53: 3236

[19] Semmelhack M F, Schmid C R, Cortes D A, Chou C S. J Am Chem Soc, 1984, 106: 3374

[20] Markó I E, Giles P R, Tsukazaki M, Chellé-Regnaut I, Gautier A, Brown S M, Urch C J.J Org Chem, 1999, 64: 2433

[21] Hoover J M, Stahl S S. J Am Chem Soc, 2011, 133: 16901

[22] Greene J F, Hoover J M, Mannel D S, Root T W, Stahl S S. Org Process Res Dev, 2013, 17: 1247

\section{Graphical Abstract}

Chin. J. Catal., 2014, 35: 1864-1873 doi: 10.1016/S1872-2067(14)60161-3

\section{CuI/N4 ligand/TEMPO derivatives: A mild and highly efficient system for aerobic oxidation of primary alcohols}

Shufang Zhang, Chengxia Miao*, Daqian Xu, Wei Sun*, Chungu Xia

Lanzhou Institute of Chemical Physics, Chinese Academy of Sciences; University of Chinese Academy of Sciences

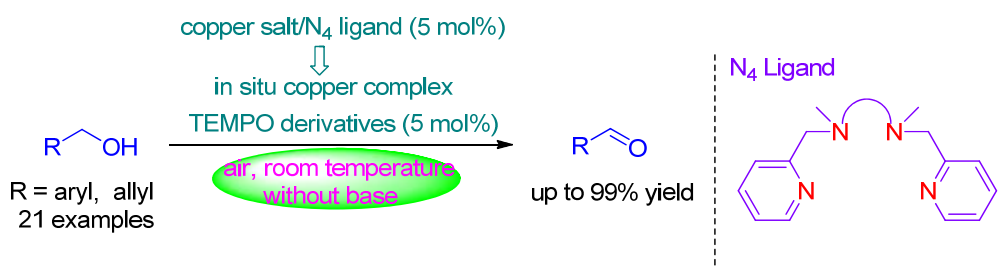

A copper(I) complex generated in situ from $N, N^{\prime}$-dimethyl- $N, N^{\prime}$-bis(2-pyridylmethyl)ethane-1,2-diamine (a tetradentate nitrogen) ligand and $\mathrm{CuI}$ in combination with 4-OH-TEMPO catalyzed the aerobic oxidation of primary benzyl and allyl alcohols at room temperature. 
[23] Steves J E, Stahl S S. J Am Chem Soc, 2013, 135: 15742

[24] Hoover J M, Ryland B L, Stahl S S. ACS Catal, 2013, 3: 2599

[25] Hoover J M, Ryland B L, Stahl S S. J Am Chem Soc, 2013, 135: 2357

[26] Mannam S, Alamsetti S K, Sekar G. Adv Synth Catal, 2007, 349: 2253

[27] Jiang N, Ragauskas A J. ChemSusChem, 2008, 1: 823

[28] Lu Z L, Costa J S, Roubeau O, Mutikainen I, Turpeinen U, Teat S J, Gamez P, Reedijk J. Dalton Trans, 2008: 3567

[29] Velusamy S, Punniyamurthy T. EurJ Org Chem, 2003: 3913

[30] Contel M, Izuel C, Laguna M, Villuendas P R, Alonso P J, Fish R H. Chem Eur J, 2003, 9: 4168

[31] Miao C X, Wang J Q Yu B, Cheng W G, Sun J, Chanfreau S, He L N, Zhang S J. Chem Commun, 2011, 47: 2697

[32] Miao C X, He L N, Wang J L, Wu F. J Org Chem, 2010, 75: 257
[33] Miao C X, He L N, Wang J Q, Gao J. Synlett, 2009: 3291

[34] Miao C X, He L N, Wang J Q, Wang J L. Adv Synth Catal, 2009, 351: 2209

[35] Karmakar T K, Aromi G, Ghosh B K, Usman A, Fun H K, Mallah T, Behrens U, Solans X, Chandra S K.J Mater Chem, 2006, 16: 278

[36] Yu S J, Miao C X, Wang D Q, Wang S F, Xia C G, Sun W. J Mol Catal A, 2012, 353-354: 185

[37] Semmelhack M F, Chou C S, Cortés D A.J Am Chem Soc, 1983, 105: 4492

[38] Wang X L, Liu R H, Jin Y, Liang X M. Chem Eur J, 2008, 14: 2679

[39] Liu R H, Liang X M, Dong C Y, Hu X Q. J Am Chem Soc, 2004, 126: 4112

[40] Cole R B. Electrospray Ionization Mass Spectrometry: Fundamentals, Instrumentation, and Applications. New York: Wiley, 1997

\title{
基于四氮配体的铜配合物/TEMPO催化的苄醇与烯丙基醇的氧化反应
}

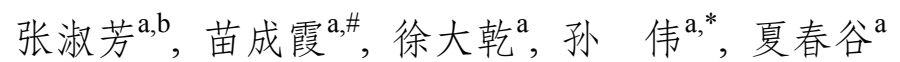 \\ a 中国科学院兰州化学物理研究所羰基合成与选择氧化国家重点实验室, 甘肃兰州730000 \\ ${ }^{\mathrm{b}}$ 中国科学院大学, 北京 100049
}

摘要: 发展了非血红素类四氮配体的铜配合物和2,2,6,6-四甲基哌啶-氮-氧自由基(TEMPO)相结合的催化体系, 应用于分子氧参与 的伯醇氧化反应. 该体系具有条件温和、高效、高选择性、无需任何助剂和底物(包括芐醇、烯丙基醇和含杂原子伯醇)使用性强 等优点. 此外, 利用高分辨质谱和紫外-光谱等对反应活性中间体进行了初步探讨.

关键词: 醇; 需氧氧化; 四氮配体; 铜; 2,2,6,6-四甲基哌啶-氮-氧自由基

收稿日期: 2014-05-01. 接受日期: 2014-06-03. 出版日期: 2014-11-20.

*通讯联系人. 传真: (0931)8277088; 电子信箱: wsun@licp.cas.cn

\#通讯联系人. 电子信箱: chxmiao@licp.cas.cn

基金来源: 国家自然科学基金(21103207, 21133011).

本文的英文电子版由Elsevier出版社在ScienceDirect上出版(http://www.sciencedirect.com/science/journal/18722067).

\section{1. 前言}

含氮配体的金属配合物作为单氧酶活性位点的模 型在有机反应尤其是氧化反应中备受关注 ${ }^{[1-3]}$. 近年来, 随着仿生催化技术的发展, 为模拟在生物代谢过程中发 挥重要作用的金属卟啉, 如细胞色素P $450^{[1]}$, 科学家们合 成了一系列四氮配体并将其配合物应用到许多反应体 系中 ${ }^{[4-7]}$. 我们课题组也在四氮配体及其金属配合物催 化烯烃不对称环氧化方面取得了一定进展 ${ }^{[8-10]}$. 然而, 有关四氮配体配合物用于催化醇的氧化反应却未见报 道.

醛酮类化合物是药物、塑料、香料及染料生产中重 要的中间体, 因此醇被选择性地氧化成相应的醛、酮化 合物在有机合成中发挥着重要作用. 近年来, 基于 2,2,6,6-四甲基哌啶-氮-氧自由基(TEMPO)的催化体系成 为实现醇氧化反应的重要方法 ${ }^{[1-13]}$. 但这类体系催化的 氧化反应往往需要化学计量的氧化剂, 如次氯酸钠和高 价碘(III)等, 因此在反应过程中会产生大量有毒副产
物 ${ }^{[14,15]}$, 且所需反应时间较长, 反应温度较高 ${ }^{[16]}$.

从绿色化学角度考虑, 选择高效、环保的醇氧化方 法, 以空气、氧气和过氧化氢为清洁氧源尤为重要. 然 而, 成本较高的TEMPO并不能直接活化氧气, 必须有共 催化剂参与 ${ }^{[17]}$.

铜配合物作为半乳糖单核铜酶的功能化模型成为 人们的研究热点 ${ }^{[18]}$. 早在 1984 年, Semmelhack课题组 ${ }^{[19]}$ 首次报道了 $\mathrm{CuCl} / \mathrm{TEMPO} / \mathrm{DMF}$ 催化体系, 当向体系中加 入 $10 \% \mathrm{CuCl} / \mathrm{TEMPO}$ 时, 室温下就可高效、高选择性地 实现苠醇和烯丙基醇的氧化. 之后, 有关醇氧化的研究 主要集中在含氮配体的设计上, 如 1,10-邻二氮菲 ${ }^{[20]}$ 、

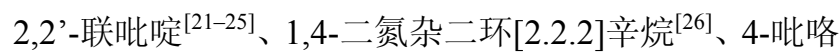
烷基吡啶 ${ }^{[27]}$ 、咪唑-吡啶类 ${ }^{[28]}$ 、salen- $\mathrm{H}_{4}{ }^{[29]}$ 和 1,4,7-氮杂 壬烷 ${ }^{[30]}$ 等. Stahl 课题组 ${ }^{[21-25]}$ 发现, 在 $\mathrm{Cu}(\mathrm{OTf})$-联吡啶 /TEMPO催化体系中加入一定量的氮甲基咪唑, 即可在 空气或氧气存在下高效、高选择性地实现苠醇、烯丙基 醇、脂肪族伯醇及含杂原子的伯醇的氧化. 该体系的不 足之处在于所用铜盐 $\mathrm{Cu}(\mathrm{OTf})$ 为非商品化药品, 且制备 
过程较为复杂.

尽管 TEMPO/Cu体系在催化分子氧参与的醇氧化 反应方面取得了较大进展, 但在温和条件下利用简单的 催化体系高效、高选择性地实现醇氧化反应仍是难点.

鉴于我们课题组在TEMPO催化醇氧化体系 ${ }^{\left[{ }^{[1-34]}\right.}$ 及 四氮配体合成和应用方面的经验 ${ }^{[8-10]}$, 我们推断四氮配 体/亚铜离子和TEMPO相结合的体系可能较好地催化醇 氧化反应(图式1), 实验结果发现 $\mathrm{Cu}(\mathrm{BPMEN}) \mathrm{I} / \mathrm{TEMPO}$ 催化体系在室温下, 以空气为氧化剂, 无需添加任何助 剂就可以高效、高选择性地实现苠醇和烯丙基醇的氧化.

\section{2. 实验部分}

\section{1. 仪器信息}

采用Agilent公司7890A/5975C型气相色谱-质谱联 用仪记录气相色谱-质谱图. 用Bruker Avance III型 400 $\mathrm{MHz}$ 核磁共振仪测定 ${ }^{1} \mathrm{H}$ NMR 和 ${ }^{13} \mathrm{C}$ NMR谱图(化学位移 和耦合常数分别用百万分之一(ppm)和Hz表示). 气相色 谱图用Agilent公司带有离子火焰化检测器的6820型仪 器记录. 采用Bruker Daltonics micro TOF-QII 型质谱仪 记录高分辩质谱, 利用Agilent Cary 60型光谱仪检测紫 外-可见光谱. 以铂电极作工作电极, 非水 $\mathrm{Ag}^{+} / \mathrm{Ag}$ 作参比 电极, 铂丝作对电极, 采用 $\mathrm{CHI}$ 660E型恒电势器测定电 化学电极电势, 扫描速率为 $100 \mathrm{mV} / \mathrm{s}$. 化合物的元素分 析在Vario EL型元素分析仪上测定.

\section{2. 配体和配合物的制备与表征}

配体 $N, N^{\prime}$-二甲基- $N, N^{\prime}$-二(2-吡啶甲基)-1,2-乙二胺 (BPMEN), $N, N^{\prime}$-二甲基- $N, N^{\prime}$-二(2-吡啶甲基)-1,3-丙二胺 (BPMPN) 和反式- $N, N^{\prime}$-二甲基- $N, N^{\prime}$-二(2-吡定甲基)-1,2环已二胺(BPMCN)根据文献 ${ }^{[35,36]}$ 合成.

BPMEN: ${ }^{1} \mathrm{H}$ NMR $\left(\mathrm{CDCl}_{3}\right) \delta=8.54$ (ddd, $J=4.9$, 1.7, $0.8 \mathrm{~Hz}, 2 \mathrm{H}), 7.63(\mathrm{td}, J=7.7,1.8 \mathrm{~Hz}, 2 \mathrm{H}), 7.42(\mathrm{~d}, J=$ $7.8 \mathrm{~Hz}, 2 \mathrm{H}$ ), 7.14 (ddd, $J=7.4,4.9,1.0 \mathrm{~Hz}, 2 \mathrm{H}$ ), 3.69 (s, $4 \mathrm{H}), 2.65(\mathrm{~s}, 4 \mathrm{H}), 2.28(\mathrm{~s}, 6 \mathrm{H}) ;{ }^{13} \mathrm{C}$ NMR $\left(\mathrm{CDCl}_{3}\right) \delta=$ 159.4, 149.1, 136.3, 123.0, 121.9, 64.2, 55.5, 42.9.

BPMPN: ${ }^{1} \mathrm{H}$ NMR $\left(\mathrm{CDCl}_{3}\right) \delta=8.53(\mathrm{~d}, J=4.5 \mathrm{~Hz}$, 2H), $7.63(\mathrm{t}, J=8.4 \mathrm{~Hz}, 2 \mathrm{H}), 7.39$ (d, $J=7.8 \mathrm{~Hz}, 2 \mathrm{H}), 7.14$ (dd, $J=6.8,5.5 \mathrm{~Hz}, 2 \mathrm{H}), 3.65$ (s, 4H), 2.54-2.44 (m, 4H), $2.25(\mathrm{~s}, 6 \mathrm{H}), 1.83-1.73(\mathrm{~m}, 2 \mathrm{H}) ;{ }^{13} \mathrm{C}$ NMR $\left(\mathrm{CDCl}_{3}\right) \delta=$ $159.5,149.0,136.3,123.0,121.9,63.9,55.8,42.5,25.2$.

BPMCN: ${ }^{1} \mathrm{H}$ NMR $\left(\mathrm{CDCl}_{3}\right) \delta=8.42(\mathrm{dt}, J=4.9,1.3$ $\mathrm{Hz}, 2 \mathrm{H}), 7.53-7.49$ (m, 4H), 7.08-7.01 (m, 2H), 3.79 (dd, $J=48.3,14.6 \mathrm{~Hz}, 4 \mathrm{H}), 2.65-2.55(\mathrm{~m}, 2 \mathrm{H}), 2.22(\mathrm{~s}, 6 \mathrm{H})$, $1.92(\mathrm{dd}, J=10.4,2.4 \mathrm{~Hz}, 2 \mathrm{H}), 1.74-1.65$ (m, 2H), 1.22 $(\mathrm{td}, J=12.3,6.4 \mathrm{~Hz}, 2 \mathrm{H}), 1.13-1.05(\mathrm{~m}, 2 \mathrm{H}) ;{ }^{13} \mathrm{C} \mathrm{NMR}$ $\left(\mathrm{CDCl}_{3}\right) \delta=161.2,148.6,136.3,123.0,121.6,64.5,60.4$, $36.7,25.8,25.8$.

在氩气保护下, 向装有 $1.0 \mathrm{~mL} \mathrm{CH} \mathrm{CH}_{3} \mathrm{CN}$ 的反应管中加 入 $\mathrm{CuI}(47.6 \mathrm{mg}, 0.25 \mathrm{mmol})$ 和 BPMEN 配 体 (67.6 mg, $0.25 \mathrm{mmol}$ ), 室温下摚拌 $2.0 \mathrm{~h}$. 反应结束后, 蒸干溶剂, 分别用乙腈和乙醚洗涤配合物, 除去溶剂, 得到配合物 $\mathrm{Cu}$ (BPMEN)I. 其高分辨质谱表征 $\mathrm{C}_{16} \mathrm{H}_{22} \mathrm{CuN}_{4}$ [M-I] $]^{+}$: 333.1135 , 理论计算值为 333.1121 ; 其元素分析表征 $\mathrm{C}_{16} \mathrm{H}_{22} \mathrm{CuN}_{4} \mathrm{I} \cdot 0.7 \mathrm{MeCN}$ : C $42.69 \%$, H 4.96\%, N 13.45\%; 理论计算值: C 42.84\%, H 5.12\%, N 13.38\%.

\section{3. 氧化反应的一般步骤}

在 $\mathrm{Ar}$ 气保护下, 向装有 $1.0 \mathrm{~mL} \mathrm{CH} \mathrm{CH}_{3} \mathrm{CN}$ 的反应管中加 入铜盐 $(0.025 \mathrm{mmol})$ 和配体 $(0.025 \mathrm{mmol})$, 反应 $0.5 \mathrm{~h}$. 然 后依次加入 TEMPO衍生物 $(0.025 \mathrm{mmol})$ 和醇 $(0.5 \mathrm{mmol})$, 在室温下空气中反应, 通过薄层色谱观察反应进度. 反 应结束后, 以硝基苯或正壬烷为内标, 用气相色谱测得 反应转化率和收率, 或者柱分离得到分离收率.

\section{4. 部分产物的核磁数据}

苯丙炔醛: ${ }^{1} \mathrm{H}$ NMR $\left(\mathrm{CDCl}_{3}\right) \delta=9.34(\mathrm{~s}, 1 \mathrm{H}), 7.51$ (dd, $J=5.2,3.2 \mathrm{~Hz}, 2 \mathrm{H}), 7.43-7.37(\mathrm{~m}, 1 \mathrm{H}), 7.32(\mathrm{t}, J=$ $7.5 \mathrm{~Hz}, 2 \mathrm{H}) ;{ }^{13} \mathrm{C}$ NMR $\left(\mathrm{CDCl}_{3}\right) \delta=175.7,132.3,130.3$, 127.7, 118.4, 94.1, 87.4

$\alpha$-甲基肉桂醛: ${ }^{1} \mathrm{H} \mathrm{NMR}\left(\mathrm{CDCl}_{3}\right) \delta=9.47(\mathrm{~s}, 1 \mathrm{H})$, 7.45-7.39 (m, 2H), 7.38-7.25 (m, 3H), $7.16(\mathrm{~d}, J=6.7 \mathrm{~Hz}$, $1 \mathrm{H}), 1.97(\mathrm{~d}, J=1.3 \mathrm{~Hz}, 3 \mathrm{H}) ;{ }^{13} \mathrm{C}$ NMR $\left(\mathrm{CDCl}_{3}\right) \delta=$ 195.5, 149.8, 138.3, 135.2, 130.1, 129.6, 128.7, 10.9.

橙花醛: ${ }^{1} \mathrm{H}$ NMR $\left(\mathrm{CDCl}_{3}\right) \delta=9.82(\mathrm{~d}, J=8.2 \mathrm{~Hz}$, $1 \mathrm{H}), 5.80(\mathrm{~d}, J=8.2 \mathrm{~Hz}, 1 \mathrm{H}), 5.07-4.99(\mathrm{~m}, 1 \mathrm{H}), 2.51(\mathrm{t}, J$ $=7.5 \mathrm{~Hz}, 2 \mathrm{H}), 2.16(\mathrm{q}, J=7.4 \mathrm{~Hz}, 2 \mathrm{H}), 1.91(\mathrm{~d}, J=1.2$ $\mathrm{Hz}, 3 \mathrm{H}), 1.61$ (s, 3H), $1.52(\mathrm{~s}, 3 \mathrm{H}) ;{ }^{13} \mathrm{C} \mathrm{NMR}\left(\mathrm{CDCl}_{3}\right) \delta=$ 190.7, 163.7, 133.6, 128.6, 122.3, 32.5, 27.0, 25.6, 25.0, 17.7.

\section{3. 结果与讨论}

\section{1. 优化反应条件}

以苯甲醇氧化为模板反应, 对反应条件进行考察 (表1). 在反应之前先将等当量的铜盐与配体原位反应 $0.5 \mathrm{~h}$, 生成相应的配合物. 空白实验表明, 体系中不加铜 盐、TEMPO和四氮配体中任一组分均不能实现苯甲醇 的氧化反应(表1, 实验1-3对15-17). 在相同条件下, 以 
$\mathrm{CuBr}$ 为铜盐, 对不同配体进行篮选, 结果发现BPMEN为 最优配体(表1, 实验 1-3), 当反应时间为 $50 \mathrm{~min}, \mathrm{GC}$ 测得 收率可达 $99 \%$. 之后, 利用 $\mathrm{CuBr}$-BPMEN对溶剂进行篮 选(表1, 实验3-11), 发现溶剂对氧化反应也有较大影响。 当以 $\mathrm{CH}_{3} \mathrm{CN}$ 为介质时, 反应 $0.5 \mathrm{~h}$ 收率为 $69 \%$, 体系表现 出最好的活性, 而以正己烷为溶剂时, 由于配合物的溶 解性较差, 该催化体系并未表现出活性. 此外, 还考察了 不同铜盐对氧化反应的影响, 发现当以 $\mathrm{CuI}$ 为铜源, 反应 $0.5 \mathrm{~h}$, 转化率和收率分别可达 $94 \%$ 和 $92 \%$, 表现出最好的 催化活性 (表 1 , 实验 3 和 12-14), 而二价铜盐 $\mathrm{CuCl}_{2}$ 和 $\mathrm{CuBr}_{2}$ 对苯甲醇的氧化几乎没有催化活性. 该结果与 Stahl等 ${ }^{[21]}$ 报道的联吡啶/Cu(OTf)体系有所不同.

此外, 我们还比较了不同 TEMPO衍生物的催化活 性. 在氧化反应中, 大部分 TEMPO的衍生物表现出相近 的催化活性, 反应 $0.5 \mathrm{~h}$, 除 $4-\mathrm{CH}_{3} \mathrm{SO}_{2} \mathrm{O}-\mathrm{TEMPO}$ 催化的氧 化反应转化率和收率低于 $80 \%$ 外, 几乎所有 TEMPO衍生 物参与的氧化反应转化率和收率都达到 $90 \%$ 以上 $($ 表 2 , 实验 1-7). 当向体系中加入 $10 \% \mathrm{CuI}$ 和 $10 \% \mathrm{BPMEN}$, 以 空气为氧化剂, 反应 $0.5 \mathrm{~h}, 4-\mathrm{OH}-\mathrm{TEMPO}$ 表现出最好的 催化活性, 实现了苯甲醇的定量转化. 此外, 还对催化剂 和TEMPO用量进行了师选 (表 2 , 实验 8-10). 当将 $\mathrm{CuI}$ 和 BPMEN用量降低到 $5 \%$, TEMPO仍为 $10 \%$, 反应 $0.5 \mathrm{~h}$ 时, 苯甲醇氧化收率也可达到 $91 \%$ (表 2 , 实验 8 )。进一步降 低催化剂量至 $2 \%$, 反应 $1.5 \mathrm{~h}$, 也可达到相当高的收率(表 2 , 实验 9$)$. 当 $\mathrm{CuI}$, BPMEN和TEMPO用量都为 $5 \%$ 时, 反 应 $1 \mathrm{~h}$ 后, 也可实现苯甲醇定量转化(表2, 实验 10 ).

\section{2. 底物拓展}

在最优条件下对该催化体系进行了底物拓展(表3). 结果发现, 几乎所有的苄醇都可以被高效氧化, 收率可 达 $85 \%$ 以上, 且无酸生成. 但是, 该体系易受电子效应和 空间位阻影响. 对甲氧基苯甲醇相比邻、间位表现出更 好的反应活性(表 3 , 实验 2-4), 且苯环上带有的供电子基 越多, 反应活性越高(表3, 实验2-4对5-6), 供电子能力越 强, 越有利于氧化反应发生(表3, 实验2-4对7-8).

对于茮醇氧化, 当苯环带有供电子基时, 反应要比 带吸电子基的茮醇的氧化容易得多. 如苯环上带有甲 基、甲氧基和异丙基时, 反应可以在空气中2.0-4.0 h完 成; 而当苯环上带有氯或澳等吸电子基时, 反应则必须 在氧气中进行, 且需要 $24 \mathrm{~h}$ 才能达到相当的转化率和收 率(表3, 实验9-12). 除此之外, 还考察了带有杂原子伯 醇的氧化, 如呋喃甲醇和噻吩甲醇都可以在常温下空气 中氧化, 可以得到 $90 \%$ 的醛(表3, 实验 13-14), 但对于吡
啶甲醇的氧化, 收率只有 $8 \%$ (表 3 , 实验 15 )。该催化体系 除了适用于苄醇氧化之外, 还适用于烯丙基醇的氧化, 如肉桂醇和橙花醇等(表3, 实验16-18). 另外, 炔丙基醇 如3-苯基-2-丙炔-1-醇在该体系中氧化也能得到 51\%的 收率 (表 3 , 实验 19$)$ 。该体系对脂肪族伯、仲醇氧化的催 化效率较低, 生成的苯乙醛和苯乙酮收率仅为 $15 \%$ 和 $7 \%$ (表 3 , 实验20和 21 ).

研究结果表明, $\mathrm{Cu}$ (BPMEN)I/4-OH-TEMPO体系适 用于催化茮醇和烯丙基伯醇的氧化, 而对仲醇的氧化效 果较差. 因此, 利用苯甲醇和 $\alpha$-苯乙醇在同一体系中竞 争氧化, 考察了该催化体系的化学选择性. 将苯甲醇 (54.1 mg, $0.5 \mathrm{mmol}$ )和 $\alpha$-苯乙醇 $(61.1 \mathrm{mg}, 0.5 \mathrm{mmol}$ ) 同时 加入到催化体系中, 反应 $0.5 \mathrm{~h}$, 薄层色谱跟踪检测, 苯甲 醇全部转化为苯甲醛, 而 $\alpha$-苯乙醇不发生反应. 此结果 表明, Cu(BPMEN)I/4-OH-TEMPO体系对催化茮醇和烯 丙基醇氧化具有很好的选择性.

Semmelhack等 ${ }^{[19]}$ 认为在 $\mathrm{CuCl} / \mathrm{TEMPO} / \mathrm{DMF}$ 催化醇 氧化反应中有 $\mathrm{TEMPO}^{+}$的参与; 且 $\mathrm{TEMPO}^{+}$在许多催化 体系中都得到认可 ${ }^{[37-39]}$. Stahl课题组 ${ }^{[21-25]}$ 基于动力学研 究, 发现TEMPO ${ }^{+}$并不是 $\mathrm{Cu}(\mathrm{OTf})$-联吡啶/TEMPO催化体 系的活性物种. 电化学表征也表明在该反应条件下 $\mathrm{Cu}^{\mathrm{II}}$ 不能氧化 TEMPO生成 TEMPO ${ }^{+}$. 由于 $\mathrm{Cu}(\mathrm{BPMEN}) \mathrm{I} /$ 4-OH-TEMPO催化体系与 $\mathrm{Cu}(\mathrm{OTf})$-联吡啶/TEMPO体系 存在一定的相似性 ${ }^{[21-25]}$, 我们也利用电化学方法(以非 水银电极作参比)测定了 $\mathrm{Cu}(\mathrm{BPMEN}) \mathrm{I} / \mathrm{TEMPO}$ 催化体系 中的氧化还原电势。将 $\mathrm{CuI}(11.4 \mathrm{mg}, 0.06 \mathrm{mmol})$, BPMEN (16.2 mg, $0.06 \mathrm{mmol}$ ) 和4-OH-TEMPO (10.3 mg, $0.06 \mathrm{mmol}$ )加入到 $3.0 \mathrm{~mL} \mathrm{CH} \mathrm{CH}_{3} \mathrm{CN}$ 中, 并在 $\mathrm{Ar}$ 气氛围下摚 拌 $5 \mathrm{~min}$, 实验测得该体系中两个电极电势 $0.35 \mathrm{~V}$ 和 -0.09 $\mathrm{V}\left(\mathrm{vs} \mathrm{Fc}^{+} / \mathrm{Fc}\right)$ 分别对应于 4-OH-TEMPO $/ 4-\mathrm{OH}-\mathrm{TEMPO}$ 和 $\mathrm{Cu}(\mathrm{BPMEN})^{\mathrm{II}} / \mathrm{Cu}(\mathrm{BPMEN})^{\mathrm{I}}$ (图 1), 反应体系中 $4-\mathrm{OH}-$ $\mathrm{TEMPO}^{+} / 4-\mathrm{OH}-\mathrm{TEMPO}$ 的电极电势接近于 $4-\mathrm{OH}-$ $\mathrm{TEMPO}^{+} / 4-\mathrm{OH}-\mathrm{TEMPO}$ 本身的电极电势(图2). 此外, 向 $\mathrm{CuI}$ 的 $\mathrm{CH}_{3} \mathrm{CN}$ 溶液中加入等当量配体BPMEN, 由于发生 配位作用, 增加了中心金属离子的电子云密度, 因此电 极电势从 $0.3 \mathrm{~V}$ 降低到 $-0.09 \mathrm{~V}$ (图3和图4), 该实验结果 与 $\mathrm{Stahl}$ 体系中所测结果一致 ${ }^{[21]}$, 当有配体存在时 $\mathrm{Cu}^{\mathrm{II}}$ 不 能氧化TEMPO生成TEMPO ${ }^{+}$.

我们还利用高分辨质谱(ESI-MS $)^{[40]}$ 对反应机理进 行了研究. 在惰气气氛下, 等当量的 CuI 和BPMEN在 $\mathrm{CH}_{3} \mathrm{CN}$ 中摚拌 $0.5 \mathrm{~h}$, 利用高分辨质谱发现, $\mathrm{CuI}$ 和 BPMEN 可发生配位作用生成 $[\mathrm{Cu}(\mathrm{BPMEN})]^{+}\left(M_{\mathrm{r}} / z=\right.$ 
333.1121). 元素分析也证实了该体系中配合物 $\mathrm{Cu}$ (BPMEN)I的生成. 然后分别向空气存在和惰气保护 的体系中加入等当量的4-OH-TEMPO, 在惰气保护的体 系中, 高分辨质谱很容易捕捉到4-OH-TEMPO $\left([\mathrm{M}+\mathrm{Na}]^{+}\right.$ $\left.M_{\mathrm{r}} / z=195.1227\right)$, 而在空气存在的体系中没有捕捉到 4-OH-TEMPO, 说明4-OH-TEMPO必须在氧气参与下才 能与 CuI和BPMEN作用生成可能的活性中间体.

紫外-可见光谱(UV-vis)也为醇氧化机理解释提供 了一定依据. 将等当量的 $\mathrm{CuI}$ 和 BPMEN溶于 $\mathrm{CH}_{3} \mathrm{CN}(5.0$ $\mathrm{mmol} / \mathrm{L})$, 在 $\mathrm{Ar}$ 气氛围下搅拌 $0.5 \mathrm{~h}$, 利用 $U V$-vis检测发现, 在705 nm处有一个很强的吸收峰对应于 $\mathrm{Cu}^{\mathrm{I}}(\mathrm{BPMEN})$ 的 配合物. 当向体系中通入空气并加入4-OH-TEMPO (5 $\mathrm{mmol} / \mathrm{L}$ ) 时, $705 \mathrm{~nm}$ 处的吸收峰逐渐消失, 而在 $810 \mathrm{~nm}$ 出 现了最大吸收峰, 加入底物之后, 随着反应的进行, 810 $\mathrm{nm}$ 处的吸收峰逐渐降低直至消失, 最后在 $675 \mathrm{~nm}$ 出现了 最大吸收. 因此我们推测对应于 $810 \mathrm{~nm}$ 的吸收峰可能为 该体系活性中间体的峰(图5).

\section{4. 结论}

发展了一个简单、有效且高选择性的CuI/BPMEN/ 4-OH-TEMPO催化体系, 该体系能够在温和条件下催化 芐醇和烯丙基醇的有氧氧化生成相应的醛, 且无酸生成. 电化学实验表明 $\mathrm{Cu}^{\mathrm{II}}$ 不能氧化TEMPO生成TEMPO ${ }^{+}$. 高 分辨质谱证实4-OH-TEMPO必须在配合物 $\mathrm{Cu}$ (BPMEN)I 和空气同时参与的情况下才能发生转化. 紫外-可见光 谱表明, $\mathrm{Cu}$ (BPMEN)I和4-OH-TEMPO能够在空气氛围 下生成可能的活性中间体. 有关该体系的催化醇氧化机 理及其在其他氧化反应中的应用有待于进一步研究. 